
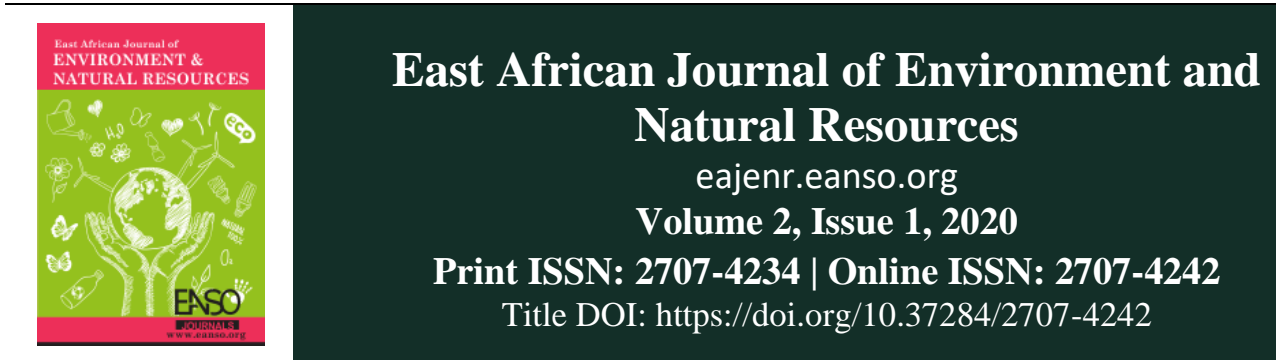

Original Article

\title{
Determinants of Adoption of Indigenous Strategies for Climate Change Adaptation among the Tharaka People in Tharaka Nithi County, Kenya
}

\author{
Caxton Gitonga Kaua ${ }^{1 *}$, \\ ${ }^{1}$ Wangari Maathai Institute of Peace and Environment Studies, University of Nairobi, P. O. Box 10718 - 00200, Nairobi, Kenya. \\ *Author for Correspondence email: Caxtonk2008@ gmail.com \\ ORCID: https://orcid.org/0000-0003-4231-9127
}

Article DOI: https://doi.org/10.37284/eajenr.2.1.139

\section{Date Published: ABSTRACT}

01 May 2020 This study envisaged analyzing factors affecting the adoption of indigenous climate change adaptation strategies among the Tharaka People in Tharaka

Keywords: Nithi County, Kenya. The study used descriptive research design and employed multi-stage sampling design. Data collection involved the collection of primary

Adoption, and secondary data. Data analysis was done using descriptive analysis and

Climate Change, Spearman's rank correlation analysis. The study concluded that the adoption of

Climate Change indigenous climate change adaptation strategies is subject to prevailing socio-

Adaptation, economic and institutional factors that affect it. These socioeconomic factors

Determinants of include age, local experience, land size, income level and income diversity that

Adoption, have a significant positive relationship thus influence on adoption. On the other

Indigenous Climate hand, other socioeconomic factors including household dependency and Change Adaptation education have a negative thus influence on adoption. Moreover, institutional factors including market access, information access, credit access, participation in community activities and membership to social networks have a significant positive relationship with adoption of indigenous climate change adaptation strategies. Conversely, other institutional factors including access to extension service and individualization of land tenure have a significant negative relationship with adoption of indigenous climate change adaptation strategies. Perception of climate has a positive relationship with the adoption of indigenous climate change adaptation strategies. These factors need to be leveraged upon in the development of policies and programs aimed at enhancing adaptation of climate change in indigenous communities.

\section{APA CITATION}

Kaua, C. (2020). Determinants of Adoption of Indigenous Strategies for Climate Change Adaptation among the Tharaka People in Tharaka Nithi County, Kenya. East African Journal of Environment and Natural Resources, 2(1), 31-41. https://doi.org/10.37284/eajenr.2.1.139. 


\section{CHICAGO CITATION}

Kaua, Caxton. 2020. "Determinants of Adoption of Indigenous Strategies for Climate Change Adaptation Among the Tharaka People in Tharaka Nithi County, Kenya". East African Journal of Environment and Natural Resources 2 (1), 31-41. https://doi.org/10.37284/eajenr.2.1.139.

\section{HARVARD CITATION}

Kaua, C. (2020) "Determinants of Adoption of Indigenous Strategies for Climate Change Adaptation among the Tharaka People in Tharaka Nithi County, Kenya", East African Journal of Environment and Natural Resources, 2(1), pp. 31-41. doi: 10.37284/eajenr.2.1.139.

\section{IEEE CITATION}

C. Kaua, "Determinants of Adoption of Indigenous Strategies for Climate Change Adaptation among the Tharaka People in Tharaka Nithi County, Kenya”, EAJENR, vol. 2, no. 1, pp. 31-41, May. 2020.

\section{MLA CITATION}

Kaua, Caxton. "Determinants of Adoption of Indigenous Strategies for Climate Change Adaptation Among the Tharaka People in Tharaka Nithi County, Kenya". East African Journal of Environment and Natural Resources, Vol. 2, no. 1, May. 2020, pp. 31-41, doi:10.37284/eajenr.2.1.139.

\section{INTRODUCTION}

IPCC (2007), notes that global warming is now indisputable given the observed increases in global average air and ocean temperatures, widespread melting of ice and rising global average sea levels. Global temperatures have risen by 1 degree centigrade since 1850 while glaciers and ice sheets are melting across the globe as temperature records are increasingly broken (Kirkland, 2012). Besides, the average global surface temperature is likely to rise by 1.8 to 4 degrees centigrade by the year 2100 and the sea level rise may rise by 30 to 60 centimetres (IPCC, 2007). Greater intensity and frequency of droughts, floods and storms due to climate change will constrain economic development (Nelson et al., 2008) and decrease agricultural productivity (Easterling, 2007). This is especially in developing countries which are characterized by multiple stresses and low adaptive capacity (1PCC, 2007).

Due to over-dependence on climate-sensitive natural resources, the habitation of fragile ecosystems and marginalization, indigenous people are the most vulnerable to climate change (Edgar et al., 2004). Indigenous people's climate change adaptation strategies based on their knowledge systems offer the best option in addressing current and future impacts of climate change (Nyong, Adesina \& Elasha, 2007). These strategies have enabled them to adapt to changes in their environments for a very long time (Shizha \& Abdi, 2014).
However, indigenous knowledge has largely been assumed, is largely undocumented, inaccessible and quickly getting eroded. It has thus not been considered in the design of modern climate change adaptation strategies (Nyong, Adesina \& Elasha, 2007) that are largely formulated at the national level resulting in ineffective and counterproductive measures.

Climate change adaptation interventions undertaken in Kenya's indigenous communities have been based on top-down approaches that do not recognize the existing knowledge systems. The interventions are not based on detailed analysis of local perceptions of climate change, the existing indigenous adaptation strategies nor the factors that influence their adoption. The interventions are thus often out of context, poorly targeted and counterproductive. Linkages between information generated by indigenous people and conservation policies and practices pursued by authorities are virtually nonexistent (Bisong \& Essien, 2010).

This is more so in among the Tharaka people in Tharaka Nithi County, Kenya who are severely negatively impacted by climate change. The study, therefore, envisioned to understand the local people's perceptions, identify existing indigenous adaptation strategies and analyze factors affecting their adoption. The area has been severely affected by the climate change given their inherent vulnerabilities as an indigenous community. 


\section{MATERIALS AND METHODS}

\section{Study area}

The study targeted the Tharaka people of Tharaka Nithi County form part of Kenya indigenous population. Tharaka Nithi County has a total population of 393,177 people living in 109,860 households (Government of Kenya, 2019). It has a surface area of 2,504.4 $\mathrm{Km}^{2}$ and a population density of 37 persons per $\mathrm{Km}^{2}$ (Government of Kenya, 2019). The population is largely agropastoral consisting of three livelihood zones which include the: mixed farming zone, marginal mixed farming and the rain-fed/irrigation farming zone (Government of Kenya, 2008). Tharaka Nithi County is part of Kenya's ASALs (Kirraine, Sharkey \& Naess, 2013). Its rainfall pattern is bimodal fluctuating between 500 to $800 \mathrm{~mm}$ per annum while temperatures range between 24 to 37 degrees centigrade (Government of Kenya, 2005) at times rising to 40 degrees centigrade (Kabui, 2012).
It is constituted of four agroecological zones namely the: lower midland 4 , lower midland 5 , intermediate lowland 5 and the intermediate lowland 6 (Owino et al., 2014).

\section{Study design}

The study used descriptive research design

\section{Sampling Design and Data Collection}

The sampling used multistage sampling design. Firstly, three sub-locations were purposively selected, each representing one of the three major agroecological zones and livelihood zones. Secondly, Systematic sampling was then be used to select individual respondent's households from each of the three sublocations. This involved sampling $10 \%$ of the total households in each of these sub-locations selected for the study. The sample size arrived at is as shown in Table 1.

Table 1: Sample size determination

\begin{tabular}{lllll}
\hline $\begin{array}{l}\text { Sampling } \\
\text { area }\end{array}$ & Agroecological zone & Livelihood zone & $\begin{array}{l}\text { Number of } \\
\text { households }\end{array}$ & $\begin{array}{l}\text { Sample size (10\% of } \\
\text { total Households) }\end{array}$ \\
\hline Tubui & Lower midland 4 & $\begin{array}{l}\text { Rain-fed/irrigation } \\
\text { farming }\end{array}$ & 292 & 29 \\
Gaceraka & Lower midland 5 & Mixed farming & 476 & 48 \\
Kamanyaki & Intermediate lowland 5 & Marginal mixed farming & 282 & 28 \\
Total & & & $\mathbf{1 0 5 0}$ & $\mathbf{1 0 5}$ \\
\hline
\end{tabular}

Data collection involved the collection of secondary and primary data. Secondary data collection involved review of previous topic related literature especially on the study area including journals, research papers, discussion paper and reports. Primary data was collected through observation, focused group discussions, key informant interviews and household questionnaire survey. Results from the various methods were crosschecked, validated and harmonized using methodological triangulation.

The data collection tools were tested for reliability using the test-retest method. In doing this, 10 questionnaires were administered to a sample outside the selected sampling areas and then re- administered to the same respondents after two weeks. The two results were then and a correlation coefficient of 0.671 arrived at indicating good reliability. Validity analysis was done based on expert consultation.

\section{Data Analysis Methods and Procedures}

Data was analyzed using descriptive analysis, thematic analysis and Spearman's' rank correlation coefficient. This was done with the aid of SPSS 20.0 statistical software.

A households' level of adoption was measured based on the use of indigenous strategies for various aspects of climate change adaptation. 
East African Journal of Environment and Natural Resources, Volume 2, Issue 1, 2020

Article DOI: https://doi.org/10.37284/eajenr.2.1.139

\section{RESULTS AND DISCUSSIONS}

Table 2: Description of socioeconomic and institutional characteristics in Tharaka Nithi County

\begin{tabular}{|c|c|}
\hline Variable & Percentage \\
\hline Age & $\begin{array}{l}1 \text { to } 35 \text { years }=33.3 \% \\
>35 \text { to } 50 \text { years }=21.9 \% \\
>50 \text { to } 65 \text { years }=16.2 \%\end{array}$ \\
\hline Credit access & $\begin{array}{l}\text { No access }=28.6 \% \\
1 \text { to } 2 \text { times }=29.5 \% \\
3 \text { to } 4 \text { times }=26.7 \% \\
>4 \text { times }=15.2 \%\end{array}$ \\
\hline Education level & $\begin{array}{l}\text { None }=23.8 \% \\
\text { Lower primary school }=33.3 \% \\
\text { Upper primary school }=27.6 \% \\
\text { Post primary education }=15.2 \%\end{array}$ \\
\hline Extension service access & $\begin{array}{l}\text { No access }=41 \% \\
1 \text { to } 3 \text { times }=25.7 \% \\
4 \text { to } 6 \text { times }=19 \% \\
>6 \text { times }=14.3 \%\end{array}$ \\
\hline Gender & $\begin{array}{l}\text { Female }=25.7 \% \\
\text { Male }=74.7 \%\end{array}$ \\
\hline Household dependency & $\begin{array}{l}\text { No dependency }=21.9 \% \\
>0 \text { to } 25 \% \text { dependency }=33.3 \% \\
25 \% \text { to } 50 \% \text { dependency }=21.9 \% \\
>50 \% \text { dependency }=22.9 \%\end{array}$ \\
\hline Household size & $\begin{array}{l}1 \text { to } 4 \text { members }=13.3 \% \\
5 \text { to } 6 \text { members }=36.2 \% \\
7 \text { to } 8 \text { members }=34.3 \% \\
>8 \text { members }=16.2 \%\end{array}$ \\
\hline Income diversity & $\begin{array}{l}1 \text { Income source }=13.3 \% \\
2 \text { Income sources }=33.3 \% \\
3 \text { Income sources }=41.9 \% \\
>3 \text { Income sources }=11.4 \%\end{array}$ \\
\hline Income level & $\begin{array}{l}\text { KES } 0 \text { to } 50000=23.8 \% \\
\text { KES } 50000 \text { to } 100000=27.6 \% \\
\text { KES } 100000 \text { to } 150000=26.7 \% \\
\text { KES }>150000=21.9 \%\end{array}$ \\
\hline Information access & $\begin{array}{l}1 \text { Source of information }=21 \% \\
2 \text { Sources of information }=28.6 \% \\
3 \text { Sources of information }=31.4 \% \\
>3 \text { Sources of information }=19 \%\end{array}$ \\
\hline Land size & $\begin{array}{l}>0-2 \text { Acres }=39 \% \\
>2-3 \text { Acres }=17.1 \% \\
>3-4 \text { Acres }=21 \% \\
>4 \text { Acres }=22.9 \%\end{array}$ \\
\hline Local livelihood experience & $\begin{array}{l}1 \text { to } 25 \text { Years' experience }=28.6 \% \\
26 \text { to } 40 \text { Years' experience }=32.4 \% \\
41 \text { to } 55 \text { Years' experience }=21.9 \% \\
>55 \text { Years' experience }=17.1 \%\end{array}$ \\
\hline
\end{tabular}


East African Journal of Environment and Natural Resources, Volume 2, Issue 1, 2020

Article DOI: https://doi.org/10.37284/eajenr.2.1.139

\begin{tabular}{ll}
\hline Variable & Percentage \\
\hline Market access & 1 to 2 times per month $=11.4 \%$ \\
& 3 to 4 times per month $=28.6 \%$ \\
& 5 to 6 times per month $=36.2 \%$ \\
& $>6$ times per month $=23.8 \%$ \\
\hline Participation level & No development meetings attended $=61 \%$ \\
& 1 to 2 development meetings $=17.1 \%$ \\
& 3 to 4 development meetings $=14.3 \%$ \\
& $>4$ development meetings $=7.6 \%$ \\
\hline Membership to social networks & Doesn't belong to any group $=18.1 \%$ \\
& Member of 1 group $=36.2 \%$ \\
& Membership to 2 groups $=29.5 \%$ \\
& Membership to $>2$ groups $=16.2 \%$ \\
\hline Perception of climate change & High perception $=76.2 \%$ \\
& Moderate perception $=16.2 \%$ \\
& Low perception $=7.6 \%$ \\
\hline
\end{tabular}

A Spearman's rank correlation was calculated to find the relationship between age and adoption of indigenous climate change adaptation strategies. A positive significant correlation ( $\mathrm{r} 0.666, \mathrm{p}<0.01$ ) was found (Table 3).

This implies the adoption of indigenous climate change adaptation strategies increases with age. This could be due to older farmers having more knowledge and experience on indigenous methods and a better understanding of local climate change. The younger farmers are more receptive to modern methods and thus could shun the indigenous ones. This is in agreement with Ziervogel and Zermoglio (2009) and Gbetibouo (2009).

Moreover, a Spearman's rank correlation was calculated between credit access and adoption of indigenous climate change adaptation strategies. A significant positive correlation ( $\mathrm{r} 0.516, \mathrm{p}<0.01$ ) was found. This means the adoption of indigenous climate change adaptation strategies increases with access to credit. This is because access to affordable credit increases the capacity to adopt indigenous climate change adaptation strategies. This is in agreement with Tazeze, Haji and Ketema (2012).

A Spearman's rank correlation was calculated between education and adoption of indigenous climate change adaptation strategies. A negative significant correlation $(\mathrm{r}-0.544, \mathrm{p}<0.01)$ was arrived at. This implies that a higher level of education leads to reduced adoption of indigenous climate change adaptation strategies. This could be since the modern education system is not tailored on indigenous knowledge and thus tends to erode it, interrupt channels of its transmission and inculcates values that tend to undermine it. This is in agreement with Nakashima et al., (2012).

Table 3: Correlation between socioeconomic and institutional characteristics and adoption of indigenous climate change adaptation strategies

\begin{tabular}{lll}
\hline Variable & Correlation Coefficient & Sig \\
\hline Age & $.666^{* *}$ & .000 \\
Credit access & $.516^{* *}$ & .000 \\
Education level & $-.544^{* *}$ & .000 \\
Extension service access & $-.643^{* *}$ & .000 \\
Gender & .072 & .464 \\
Household dependency & $-.534^{* *}$ & .000 \\
Household size & .051 & .605 \\
Income diversity & $.576^{* *}$ & .000 \\
Income level & $.528^{* *}$ & .000 \\
\hline
\end{tabular}


East African Journal of Environment and Natural Resources, Volume 2, Issue 1, 2020

Article DOI: https://doi.org/10.37284/eajenr.2.1.139

\begin{tabular}{lll}
\hline Variable & Correlation Coefficient & Sig \\
\hline Information access & $.633^{* *}$ & .000 \\
Land size & $.596^{* *}$ & .000 \\
Local livelihood experience & $.679^{* *}$ & .000 \\
Market access & $.590^{* *}$ & .000 \\
Participation level & $.759^{* *}$ & .000 \\
Membership to social networks & $.704^{* *}$ & .000 \\
Perception of climate change & $.735^{* *}$ & .000 \\
\hline
\end{tabular}

A Spearman's rank correlation was calculated between access to extension service and adoption of indigenous climate change adaptation strategies. A negative significant correlation $(\mathrm{r}-0.643, \mathrm{p}<0.01)$ was found. Therefore, access to extension service has leads to lower adoption of indigenous climate change adaptation strategies. This could be because extension services mostly promote modern technologies at the expense of indigenous ones leading to their erosion. About $79 \%$ of the respondents said that extension officers don't train on indigenous strategies. This is in agreement with Reid et al., (2009) and Mati (2006).

Further, a Spearman's rank correlation analysis was calculated to find out the relationship between gender and adoption of climate change adaptation

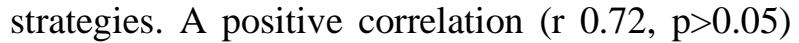
that was not significant was arrived at. Therefore, women adopt indigenous climate change adaptation strategies more. This could be due to women being more involved in land-based production activities and having less financial capacity to invest in and access to modern technologies.

A Spearman's rank correlation analysis was calculated between household dependency and adoption of indigenous climate change adaptation strategies. A negative significant correlation ( $\mathrm{r}$ $0.534, \mathrm{p}<0.01)$ was found. Greater household dependency thus reduces the capacity to adopt indigenous climate change adaptation strategies. This could be due the higher burden in taking care of the larger household. This finding is affirmed by Apata (2011).

A Spearman's rank correlation analysis was calculated between household size and adoption of indigenous climate change adaptation strategies. A positive non-significant correlation ( $\mathrm{r}$ 0.051, $\mathrm{p}<0.01)$ was found. Therefore, household size increases adoption of indigenous climate change adaptation strategies. This is because larger households have more labor force hence capacity to undertake indigenous climate change adaptation strategies. They may also be forced to divert to divert part of their labor to nonindigenous activities in a bid to cope with the higher consumption pressures. Yirga (2007) also noted the same findings.

On calculating a Spearman's correlation analysis between income diversity and adoption of indigenous climate change adaptation strategies. A positive significant correlation $(\mathrm{r}$ 0.576, $\mathrm{p}<0.01$ ) was found. This means more income diversity lead to increase in adoption of indigenous climate change adaptation strategies. Those who have more diverse income sources have more livelihood choices and more income thus greater capacity to adopt. Greater diversity also means espousal of more diverse technologies which could also include indigenous strategies. This finding is in agreement with Conway (2009) and Onubuogu, Chidebelu \& Eboh (2014).

A Spearman's rank correlation was calculated between income and adoption of indigenous climate change adaptation strategies. A positive significant correlation ( $\mathrm{r} 0.528, \mathrm{p}<0.01$ ) was found. This means income increases adoption. This could be because greater income means greater capacity to undertake indigenous strategies, more latitude in making choices. Greater income also reduces risk averseness and discount rate hence greater willingness to adopt. This finding is in agreement with CIMMYT (1993) and Nhamachena and Hassan (2007).

A Spearman's rank correlation was calculated between access to information and adoption of indigenous climate change adaptation strategies. A positive significant correlation $(\mathrm{r} 0.633, \mathrm{p}<0.01)$ was found. More access to information means 
greater knowledge and thus capacity to adopt indigenous climate change adaptation strategies. This is in agreement with Baethgen et al. (2003).

A Spearman's correlation analysis was calculated between land size and adoption of indigenous climate change adaptation strategies. A positive significant correlation ( $\mathrm{r} 0.596, \mathrm{p}<0.01$ ) was found. This means owning more land increases adoption of indigenous climate change adaptation strategies. This is because those who larger lands have more capital and resources to invest in adaptation strategies. This concurs with Gbetibouo (2009).

A Spearman's rank correlation was calculated between local livelihood experience and adoption of indigenous climate change adaptation strategies. A positive significant correlation $(\mathrm{r} 0.679, \mathrm{p}<0.01)$ was found. This is because the more experience farmers have the greater their knowledge on local climate change and indigenous practices hence increased adoption. This is in consonance with Nhamachena and Hassan (2008)

A Spearman's rank correlation was calculated between market access and adoption of indigenous climate change adaptation strategies. A positive significant correlation ( $\mathrm{r} 0.59, \mathrm{p}<0.01$ ) was found. This is because markets are avenues of information exchange. Greater to inputs and produce markets access could also mean greater access to resources. More access markets thus leads to greater capacity to adopt. This is in agreement with Maddison (2006), Tazeze, Haji \& Ketema (2010) and Gutu, Bezabih, \& Mengistu (2012).

A Spearman's rank correlation was calculated between participation in community issues and activities and adoption of indigenous climate change adaptation strategies. A positive significant correlation ( $\mathrm{r} 0.759, \mathrm{p}<0.01$ ) was found. This is because participation in community issues and activities increases access to livelihood opportunities, information and social capital hence the capacity to adoption. This is in agreement with Ofouku and Emieke (2012).

A Spearman's rank correlation was calculated between membership to social networks and adoption of indigenous climate change adaptation strategies. A significant positive correlation ( $\mathrm{r}$ $0.704, p<0.01)$ was arrived at. This is because social networks act as platforms for shared learning and channels of information exchange. They also foster access mutual support and reciprocity mechanisms and empowerment hence participation in decision making. They thus foster access to livelihood opportunities and access to capital assets including through credit schemes such as table banking. This is in agreement with Below et al. (2010) and Deressa (2009).

A spearman's rank correlation was calculated between perception of climate change and adoption of indigenous climate change adaptation strategies. A positive correlation $(\mathrm{r} 0.735, \mathrm{p}<0.01)$ was arrived at. This implies that climate change perception increases adoption of indigenous climate change adaptation strategies. This is because adoption starts with perception of the problem followed by response. Perception of climate change by the household head thus increases the household likelihood of adopting. This in agreement with findings by Assan (2014), Shongwe (2014) and Prager \& Posthumus (2010).

\section{CONCLUSION}

The study analyzed determinants of adoption of indigenous climate change adaptation strategies among the indigenous Tharaka People in Tharaka Nithi County, Kenya. Adoption of indigenous climate change adaptation strategies is subject to prevailing socioeconomic and institutional factors that affect it. These socioeconomic factors include age, local experience, land size, income level and income diversity that have a significant positive relationship thus influence on adoption. On the other hand, other socioeconomic factors including household dependency and education have a negative thus influence on adoption. Moreover, institutional factors including market access, information access, credit access, participation in community activities and membership to social networks have a significant positive relationship with adoption of indigenous climate change adaptation strategies. Conversely, other institutional factors including access to extension service and individualization of land tenure have a significant negative relationship with adoption of indigenous climate change adaptation strategies. Perception of climate has a positive relation with adoption of indigenous climate change adaptation 
strategies. These factors need to be leveraged upon in development of policies and programs aimed at enhancing adaptation of climate change in indigenous communities.

\section{REFERENCES}

Apata, T. (2011). Factors influencing the perception and choice of adaptation measures to climate change among farmers in Nigeria: Evidence from farm households in South West Nigeria. Environmental economics, 2(4), 7483.

Assan, N. (2014). Possible impacts and adaptation to climate change in livestock production in Southern Africa. IOSR Journal of environmental science, toxicology and food technology, 8(2), 104-112

Baethgen, W. E., Meinke, H., \& Gimene, A. (2003). Adaptation of agricultural production systems to climate variability and climate change: lessons learned and proposed research approach. In Climate Adaptation.net conference" Insights and Tools for Adaptation: Learning from Climate Variability (Vol. 18, p. 20). Washington D.C.

Below, T., Artner, A., Siebert, R., \& Sieber, S. (2010). Micro-level practices to adapt to climate change for African small-scale farmers. Discussion paper 00953. International Food Policy Research Institute (IFPRI).

Bisong, F., \& Andrew-Essien, E. (2010). Indigenous knowledge systems for promoting community conservation education in a Nigerian protected area. International journal of biology, 2(2), 149.

CIMMYT. (1993). Cereals production in SubSaharan Africa. New York

Conway, G. (2009). The science of climate change in Africa: impacts and adaptation. Grantham Institute for Climate Change Discussion Paper, 1, 24.

Deressa, T. (2009). A study on the perception and adaptation to climate change: the case of farmers in the Nile basin of Ethiopia. Centre for
Environmental Economics and Policy for Africa (CEEPA), University of Pretoria, South Africa.

Easterling, W. E. (2007). Food, Fibre and Forest Products. Climate Change 2007: Impacts, Adaptation and Vulnerability. In Parry, M. L. et al., Contribution of Working Group II to the Fourth Assessment Report of the Intergovernmental Panel on Climate Change (IPCC).

Esiobu, N. \& Onubougu, G. (2014). Trends, perceptions and adaptation options of arable crop farmers to climate change in Imo state Nigeria: Multinomial logit model approach. Scholarly journal of agricultural science, 4(7), 370-385

Gbetibouo, G., (2009). Understanding farmer's perception and adaptations to climate change variability. Washington DC: IFPRI

Government of Kenya. (2005). Tharaka district strategic plan 2005-2010 for implementation of the national population policy for sustainable development. NCAPD

Government of Kenya. (2008). Tharaka district short rains assessment report: 19th-22nd February 2008

Government of Kenya. (2019). 2019 Kenya population and housing census, Vol. la: Population by county and subcounty

Reid, H., Alam, M., Berger, R., Cannon, T., Huq, S., \& Milligan, A. (2009). Participatory learning and action: Community-based adaptation to climate change. International Institute for Environment and Development (IIED): London, UK, 221.

IPCC. (2007). Climate change 2007 synthesis report: Contributions of working group I, II and III to the fourth assessment report of the intergovernmental panel on climate change. Geneva, Switzerland: IPCC

Kabui, I. (2012). Household food insecurity and coping strategies among small scale farmers in Tharaka Central Division. Unpublished Masters' thesis, Kenyatta University 
Kiplagat, J., \& Rotich, D. (2008). Mapping and auditing of agricultural indigenous knowledge in Uasin Gishu and Keiyo districts in Rift Valley, Kenya. Moi University

Kirkland, E. (2012). Indigenous knowledge and climate change adaptation in the Peruvian Andes: Political economy of the environment in Latin America. INTL

Kirraine, C., Sharkey, C., \& Naess, L. O. (2013). Shaping strategies: factors and actors in climate change adaptation-Lessons from two-year case studies in Africa and Latin America. Trocaire and the Institute of Development Studies.

Maddison, D. (2006). The perception and adaptation to climate change in Africa. CEEPA Discussion paper No. 10. University of Pretoria.

Mati, B. (2006). Overview of water and soil nutrient management under small holder rain fed agriculture in East Africa. IWMI Working paper No. 105. IWMI

Mude, A.; Ouma, R.; Steeg, J. van de; Kariuki, J.; Opiyo, D.; Tipilda, A. 2007. Kenya adaptation to climate change in the arid lands: anticipating, adapting to and coping with climate risks in Kenya - operational recommendations for KACCAL. ILRI Research Report, no. 18. Nairobi (Kenya): ILRI

Nakashima, D., McLean, K. G., Thulstrup, H. D., Castillo, A. R., \& Rubis, J. T. (2012). Weathering uncertainty: traditional knowledge for climate change assessment and adaptation. Paris: UNESCO

Nhamachena, C., \& Hassan, R. (2007). Micro level analysis of farmer's perception to climate change in Southern Africa. IFPRI

Hassan, R. M., \& Nhamachena, C. (2008). Determinants of African farmers' strategies for adapting to climate change: Multinomial choice analysis. African Journal of Agricultural and Resource Economics, 2(3112016-5521), 83-104.

Nyong, A., Adesina, F., \& Elasha, B. O. (2007). The value of indigenous knowledge in climate change mitigation and adaptation strategies in the African Sahel. Mitigation and Adaptation strategies for global Change, 12(5), 787-797.

Ofouku, A., \& Emueke, E. (2012). Determinants of adaptation to climate change among arable crop farmers in Edo state, Nigeria and its implications for extension service. Journal for advanced biological research, 2(2), 220-227

Onubuogu, G. C., Chidebelu, S. A. N. D., \& Eboh, E. C. (2013). Enterprise type, size and allocative efficiency of broiler production in Imo State, Nigeria. International Journal of Applied Resources and Technologies, 2(6), 1019.

Owino, F et al., (2014). Tharaka Nithi County 2013-2014 short rains food security assessment report: 10th-14th February 2014

Prager, K., \& Posthmus, H. (2010). Socioeconomic factors influencing farmer's adoption of soil conservation practices in Europe. In T. Napier (Ed.), Human dimensions of soil and water conservation; A global perspective. Nova science publishers

Nelson, G. C., Rosegrant, M. W., Palazzo, A., Gray, I., Ingersoll, C., Robertson, R., \& Msangi, S. (2010). Food security, farming, and climate change to 2050: scenarios, results, and policy options (Vol. 172). Washington DC IFPRI.

Salick, J., \& Byg, A. (2007). Indigenous peoples and climate change. Tyndall centre

Shizha, E., \& Abdi, A. (2014). Indigenous discourses on knowledge and development in Africa. New York: Routledge

Shongwe, P. (2014). Factors influencing the choice of climate change adaptation strategies of households: A case study of Mpolonjeni area development programme in Swaziland. Journal of agricultural studies, 2(2)

Tazeze, A., Haji, J., \& Ketema, M. (2012). Climate change adaptation strategies of smallholder farmers: the case of Babilie District, East Hararghe Zone of Oromia Regional State of Ethiopia. Journal of Economics and Sustainable Development, 3(14), 1-12. 
Gutu, T., Bezabih, E., \& Mengistu, K. (2012). Econometric analysis of local level perception, adaptation and coping strategies to climate change induced shocks in North Shewa, Ethiopia. International Research Journal of Agricultural Science and Soil Science, 2(8), 347-363.

Yirga, C. (2007). The dynamics of soil degradation and incentives for optimal management in Central highlands of Ethiopia. Unpublished $\mathrm{PhD}$ thesis, University of Pretoria

Yohe, G., Malone, E., Brenkert, A., Schlesinger, M., Meij, H., Xing, X., \& Lee, D. (2006). A synthetic assessment of the global distribution of vulnerability to climate change from the IPCC perspective that reflects exposure and adaptive capacity. CIESIN (Center for International Earth Science Information Network), Columbia University, Palisades.

Ziervogel, G., \& Zermoglio, F. (2009). Climate change scenarios and the development of adaptation strategies in Africa: Challenges and opportunities. Climate research, 40, 133-146 